Situs Jurnal : http://ejournal.stiepancasetia.ac.id/index.php/jieb

Jilid 6 Nomor 2 Juli 2020

Hal 218 - 226

\title{
ANALISIS LAPORAN KEUANGAN \\ SEBAGAI ALAT UNTUK MENGUKUR KINERJA KEUANGAN \\ PADA PT. DZAKY INDAH PERKASA CABANG SUNGAI TABUK
}

\section{Khairina Ariyanti*}

\begin{abstract}
Abstrak : Tujuan dari penelitian ini adalah untuk mengetahui analisis laporan keuangan yang selama ini dan yang seharusnya sebagai alat untuk mengukur kinerja keuangan pada PT. Dzaky Indah Perkasa Cabang Sungai Tabuk. Metode yang digunakan adalah deskriptif kualitatif untuk menjelaskan dan memberikan gambaran mengenai kondisi ataupun situasi yang menjadi objek penelitian. Dengan teknik analisis data yaitu menggunakan analisis rasio keuangan yang terdiri dari rasio likuiditas, rasio solvabilitas, rasio aktivitas, rasio profitabilitas dan rasio pertumbuhan. Penelitian dilakukan pada PT. Dzaky Indah Perkasa Cabang Sungai Tabuk. Hasil penelitian menunjukkan bahwa PT. Dzaky Indah Perkasa Cabang Sungai Tabuk selama ini dalam mengukur tingkat keberhasilan suatu usaha hanya secara sederhana yaitu mengacu kepada laporan keuangan yang telah disajikan pada setiap periodenya dan yang seharusnya setelah dilakukan analisis laporan keuangan menggunakan rasio keuangan diketahui tingkat kinerja yang baik dihasilkan dari likuiditas, solvabilitas dan profitabilitas, sedangkan tingkat kinerja yang kurang baik dihasilkan dari aktivitas dan pertumbuhan.
\end{abstract}

Kata Kunci : Laporan Keuangan, Kinerja Keuangan, Rasio Keuangan.

Abstract : The purpose of this study is to find out the analysis of financial statements that have been and which should be a tool to measure financial performance at PT. Dzaky Indah Perkasa Branch of the Tabuk River. The method used is descriptive qualitative to explain and provide an overview of the conditions or situations that are the object of research. The data analysis technique is using financial ratio analysis which consists of liquidity ratios, solvency ratios, activity ratios, profitability ratios and growth ratios. The study was conducted at PT. Dzaky Indah Perkasa Branch of the Tabuk River. The results showed that PT. Dzaky Indah Perkasa Branch of Sungai Tabuk so far in measuring the success rate of a business is only simply referring to the financial statements that have been presented in each period and which should be done after analyzing financial statements using financial ratios known good performance levels resulting from liquidity, solvency and profitability, while the level of poor performance results from activity and growth.

Keywords: Financial Reports, Financial Performance, Financial Ratios. 


\section{PENDAHULUAN}

Tujuan utama didirikannya perusahaan adalah untuk memperoleh keuntungan yang maksimal namun keberhasilan perusahaan tergantung dari manajemen keuangannya. Dari kemajuan usaha tersebut pada umumnya suatu perusahaan dapat diukur keberhasilannya berdasarkan kinerja keuangan dari perusahaan. Oleh karena itu perlu diketahui suatu perusahaan harus melihat kondisi dan kinerjanya agar dapat bersaing dengan perusahaan lainnya dan juga dapat mengembangkan usaha nya tersebut. Untuk menilai kinerja suatu perusahaan dapat dilihat dari aspek keuangan dan aspek non keuangan.

Baik dan buruknya kinerja perusahaan yang dilihat dari bidang keuangannya dapat dinilai melalui laporan keuangan perusahaan yang telah disajikan pada setiap periode. Laporan keuangan tidak hanya penting bagi pihak-pihak dalam perusahaan, tetapi juga bagi pihak lainnya atau biasa disebut dengan pihak eksternal. Perusahaan perlu melakukan analisis laporan keuangan karena laporan keuangan digunakan untuk menilai kinerja perushaan dan digunakan untuk membandingkan kondisi perusahaan dari tahun yang berjalan dengan tahun sebelummnya. Informasi kinerja ini bermanfaat untuk memprediksi kapasitas perusahaan dalam menghasilkan arus kas dari sumber data yang ada. Di samping itu, informasi tersebut juga berguna dalam rumusan pertimbangan tentang efektivitas perusahaan dalam memanfaatkan tambahan sumber daya.

PT. Dzaky Indah Perkasa Cabang Sungai Tabuk merupakan perusahaan yang bergerak dalam bidang developer dengan nama perumahan Dzaky Residence yang beralamat di Jl. Martapura Lama KM 14.800 Sungai Tabuk Kota RT 001 Kabupaten Banjar Kalimantan Selatan. Pendapatan PT. Dzaky Indah Perkasa Cabang Sungai Tabuk dari tahun ke tahun berikutnya terus meningkat, begitu juga dengan perolehan keuntungannya.Walaupun keuntungan yang diperoleh juga terus meningkat dari tahun ke tahun namun belum tentu dalam kinerja keuangan pada perusahaan tersebut secara keseluruhan dalam kondisi baik sesuai dengan standar. Dalam penelitian ini salah satunya adalah pada rasio aktivitas yaitu rasio perputaran persediaan (Inventory Turnover) dimana pada tahun 2016 diperoleh 10 kali perputaran, tahun 2017 diperoleh 1 kali perputaran, dan tahun 2018 diperoleh 3 kali perputaran, sedangkan standar industri untuk perputaran persediaan adalah minimal 20 kali pada per tahunnya.

Dalam hal tersebut dinyatakan bahwa PT. Dzaky Indah Perkasa Cabang Sungai Tabuk belum mampu untuk mengembalikan dana nya yang tertanam pada persediaan yang berputar dalam suatu periode. Dimana semakin lama perputaran persediaan tersebut menjadi kas maka akan semakin lama juga perolehan keuntungan yang akan didapatkan. Maka dari itu dapat dikatakan bahwa perolehan keuntungan yang meningkat pada tahun ke tahunnya belum tentu menghasilkan kinerja keuangan dalam kondisi yang baik sesuai dengan standar berdasarkan aktivitasnya.

\section{TINJAUAN PUSTAKA}

Menurut Kasmir (2016:66), mengemukakan analisis laporan keuangan bahwa agar laporan keuangan menjadi lebih berarti sehingga dapat dipahami dan dimengerti oleh berbagai pihak, maka perlu dilakukan analisis laporan keuangan. Hasil analisis laporan keuangan juga akan memberikan informasi tentang kelemahan dan kekuatan yang dimiliki perusahaan. Dengan adanya kelemahan dan kekuatan yang dimiliki, akan tergambar kinerja manajemen selama ini.

Analisis rasio keuangan dapat diklasifikasikan ke dalam lima aspek rasio keuangan perusahaan (Kasmir:2016), yaitu:

\section{Rasio likuiditas}

Rasio Likuiditas dapat diartikan sebagai kemampuan perusahaan dalam melunasi sejumlah utang jangka pendek, umumnya kurang dari satu tahun yang mencerminkan ukuran-ukuran kinerja manajemen ditinjau dari sejauh mana manajemen mampu mengelola modal kerja 
yang didanai dari hutang lancar dan saldo kas perusahaan. Beberapa rasio yang digunakan :

1. Rasio Lancar (Current Ratio)

2. Rasio Cepat (Quick Ratio)

3. Rasio Kas (Cash Ratio)

\section{Rasio Solvabilitas}

Rasio solvabilitas digunakan untuk mengukur kemampuan perusahaan untuk membayar seluruh kewajibannya, baik jangka pendek maupun jangka panajang apabila perusahaan dilikuidasi (dibubarkan) (Kasmir, 2016:151). Rasio solvabilitas dibagi menjadi 2 jenis, yaitu:

1. Rasio Hutang Terhadap Aset (Debt to Assets Ratio)

2. Rasio Hutang Terhadap Ekuitas (Debt to Equity Ratio)

\section{Rasio Aktivitas}

Rasio aktivitas merupakan rasio yang digunakan untuk mengukur efektivitas perusahaan dalam menggunakan aset yang dimilikinya (Kasmir, 2016:172). Rasio aktivitas yang digunakan adalah:

1. Rasio Perputaran Persediaan (Inventory Turnover)

2. Rasio Perputaran Aset Tetap (Fixed Assets Turnover)

3. Rasio Perputaran Aset (Total Assets Turnover)

\section{Rasio Profitabilitas}

Rasio profitabilitas merupakan rasio untuk menilai kemampuan perusahaan dalam mencari keuntungan. Rasio ini juga memberikan ukuran tingkat efektivitas manajemen suatu perusahaan (Kasmir, 2016:196). Rasio profitabilitas dibagi menjadi 4 jenis, yaitu:

1. Rasio Margin Laba Kotor (Gross Profit Margin)

2. Rasio Margin Laba Bersih (Net Profit Margin)

3. Rasio Pengembalian Atas Aset (Return On Assets)

4. Rasio Pengembalian Atas Modal (Return On Equity)

\section{Rasio Pertumbuhan Laba}

Rasio ini menggambarkan presentasi pertumbuhan pos-pos perusahaan dari tahun ke tahun (Harahap, 2016:309). Rasio pertumbuhan dapat dihitung dengan beberapa rasio, yaitu:

1. Rasio Kenaikan Penjualan (Sales Growth)

2. Rasio Kenaikan Laba Bersih (Net Income Growth)

\section{PENELITIAN TERDAHULU}

Berikut ini adalah beberepa penelitian terdahulu yang digunakan penulis sebagai referensi :

1. Cindi Yuliane Khanjaya (2016) dengan judul "Analisis Laporan Keuangan PT. Ciputra Property Sebagai Dasar Penilaian Kinerja Perusahaan Pada Periode 20112014".

2. Muhammad Aziz Muslim (2016) dengan judul "Analisis Rasio Keuangan PT. Pembangunan Perumahan (Persero) Tahun 20132015".

3. Ahmad Faisal (2017) dengan judul "Analisis Kinerja Keuangan Pada CV. Karunia Jaya".

\section{METODE PENELITIAN}

Penelitian ini menggunakan jenis penelitian analisis deskriptif kualitatif yaitu bertujuan untuk menganalisis data-data yang dihasilkan dari laporan keuangan terhadap kinerja perusahaan. Dalam penelitian ini menggunakan berbagai teori dan melihat berbagai fakta mengenai fenomena yang ada pada PT. Dzaky Indah Perkasa Cabang Sungai Tabuk dengan tujuan menjelalaskan, meringkaskan berbagai kondisi dan berbagai situasi yang timbul menjadi objek penelitian berdasarkan apa yang terjadi, kemudian memberikan gambaran tentang kondisi, ataupun situasi tersebut. Populasi dalam penelitian ini adalah seluruh data berupa laporan keuangan yang dimiliki oleh PT. Dzaky Indah Perkasa Cabang Sungai Tabuk. Sampel dalam penelitian ini adalah laporan keuangan perusahaan selama tiga tahun terakhir yaitu tahun 2016, tahun 2017, dan tahun 2018. 


\section{Teknik Analisis Data}

Teknik analisis data yang digunakan dalam penelitian ini adalah dengan menggunakan analisis rasio keuangan. Menurut (Kasmir:2016) alat analisis rasio keuangan yang digunakan untuk menilai kinerja keuangan adalah sebagai berikut :

1. Rasio Likuiditas, beberapa rumus yang digunakan dalam rasio likuiditas adalah sebagai berikut :

$$
\begin{aligned}
& \mathrm{CR}=\frac{\text { Current Assets }}{\text { Current Liabilities }} \times 100 \% \\
& \mathrm{QR}=\frac{\text { Current Assets }- \text { Inverntory }}{\text { Current Liabilities }} \times 100 \% \\
& \mathrm{CR}=\frac{\text { Cash }}{\text { Current Liabilities }} \times 100 \%
\end{aligned}
$$

2. Rasio solvabilitas, beberapa rumus yang digunakan dalam rasio solvabilitas adalah sebagai berikut :

$$
\begin{aligned}
& \text { DAR }=\frac{\text { Total Debt (Liabilities) }}{\text { Total Assets }} \times 100 \% \\
& \text { DER }=\frac{\text { Total Debt (Liabilities) }}{\text { Total Equity }} \times 100 \%
\end{aligned}
$$

3. Rasio aktivitas, beberapa rumus yang digunakan dalam rasio aktivitas adalah sebagai berikut :

$$
\begin{aligned}
& \text { Inventory Turnover }=\frac{\text { Cost Of Goods Sold }}{\text { Inventory }} \\
& \text { Fixed Assets Turnover }=\frac{\text { Sales }}{\text { Fixed Assets }} \\
& \text { Total Assets Turnover }=\frac{\text { Sales }}{\text { Total Assets }}
\end{aligned}
$$

4. Rasio profitabilitas, beberapa rumus yang digunakan dalam rasio profitabilitas adalah sebagai berikut:

$$
\begin{aligned}
& \mathrm{GPM}=\frac{\text { Gross Profit }}{\text { Net Sales }} \times 100 \% \\
& \mathrm{NPM}=\frac{\text { Earning After Tax }}{\text { Net Sales }} \times 100 \% \\
& \mathrm{ROA}=\frac{\text { Net Income }}{\text { Total Assets }} \times 100 \%
\end{aligned}
$$

$$
\mathrm{ROE}=\frac{\text { Net Income }}{\text { Total Equity }} \times 100 \%
$$

5. Rasio Pertumbuhan Laba, beberapa rumus yang digunakan dalam rasio pertumbuhan laba adalah sebagai berikut

$$
\begin{aligned}
& \text { Sales Growt }=\frac{\text { Sales this Year }- \text { Sales last Year }}{\text { Sales last Year }} \\
& \text { Net Income Growth } \\
& =\frac{\text { Net Income this Year }- \text { Net Income last Year }}{\text { Net Income last Year }}
\end{aligned}
$$

\section{PEMBAHASAN}

Pada PT. Dzaky Indah Perkasa Cabang Sungai Tabuk yang selama ini dalam mengukur tingkat keberhasilan suatu usaha hanya mengacu kepada laporan keuangan yang dimana dapat diukur dari keuntungan ataupun kerugian yang dihasilkan dari usaha yang telah dijalankan. Dengan ini dapat dikatakan bahwa perusahaan tersebut belum melakukan analisis terhadap laporan keuangan menggunakan teknik analisis rasio keuangan sesuai dengan standar industri yang bertujuan untuk membandingkan laporan keuangan ditahun yang berjalan dengan laporan keuangan ditahun sebelumnya agar dapat mengetahui perkembangan dan kemajuan dalam menjalankan usaha tersebut.

Keuntungan bagi perusahaan apabila melakukan analisis terhadap laporan keuangan dengan menggunakan teknik anlisis rasio keuangan maka perusahaan tersebut dapat mengetahui kinerja keuangan yang sesuai dengan standar industri.

Berikut adalah analisis laporan keuangan yang seharusnya untuk mengukur kinerja dengan menggunakan teknik analisis rasio keuangan pada PT. Dzaky Indah Perkasa Cabang Sungai Tabuk : 


\section{Rasio Likuiditas}

\section{Tabel 1 : Perhitungan Rasio Lancar}

$\begin{aligned} & 2016= \frac{3.468 .030 .693}{226.862 .000} \times 100 \%=1.529 \% \\ & 2017= \frac{10.652 .356 .272}{39.362 .000} \times 100 \%=27.063 \% \\ & 2018=\frac{14.302 .915 .100}{207.850 .000} \times 100 \%=6.881 \%\end{aligned}$

Sumber : Data diolah

Standar industri untuk rasio lancar adalah minimal 200\%. Dalam hal tersebut perusahaan memiliki kemampuan yang besar untuk memenuhi kewajiban lancar dengan menggunakan aset lancar yang dimiliki. Namun jika diperoleh nilai rasio lancar yang terlalu besar maka ada kemungkinan perusahaan tersebut kurang mempergunakan aset lancar secara maksimal. Langkah yang seharusnya dilakukan adalah sebaiknya perusahaan dapat merencanakan dan mengatur ulang mengenai strategi pemasaran yang terdiri dari 4P (Product, price, place, promotion).

\section{Tabel 2 : Perhitungan Rasio Cepat}

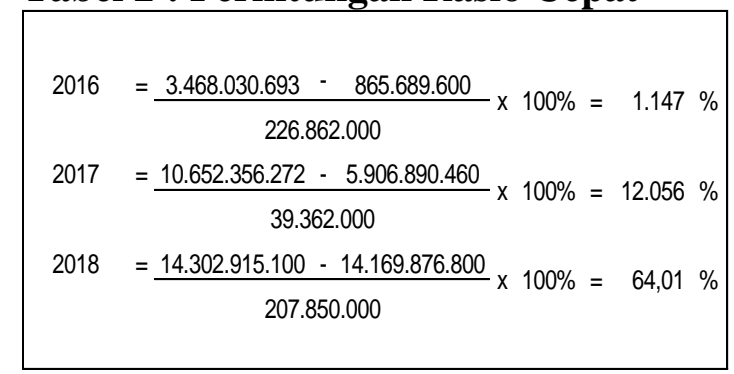

Sumber : Data diolah

Standar industri untuk rasio cepat adalah minimal $150 \%$ pada per tahunnya. Dalam hal tersebut menandakan perusahaan yang bersangkutan tidak dapat membayar kewajiban lancarnya dalam waktu yang singkat. Langkah yang seharusnya dilakukan adalah sebaiknya perusahaan dapat mengelola dana yang berasal dari kas dan setara kas untuk menghasilkan keuntungan yang optimal serta mampu untuk menutupi kewajiban lancarnya tanpa memperhitungkan nilai persediaan.
Tabel 3 : Perhitungan Rasio Kas

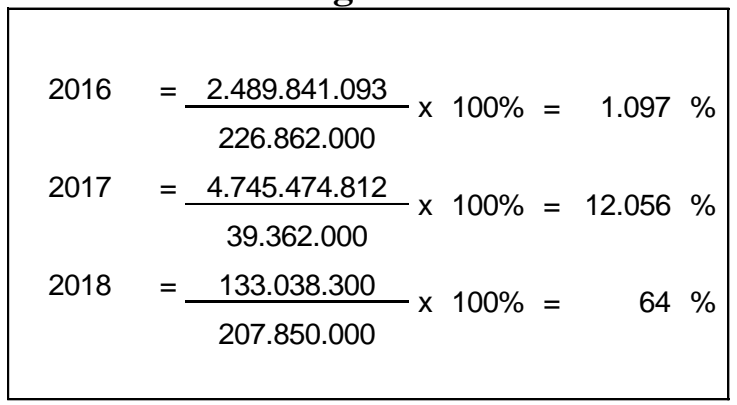

Sumber : Data diolah

Standar industri untuk rasio kas minimal 50\% pada per tahunnya. Dalam hal tersebut perusahaan memiliki kemampuan untuk memenuhi kewajiban lancarnya hanya dengan menggunakan kas perusahaan. Langkah yang seharusnya dilakukan sebaiknya perusahaan dapat menstabilkan nilai kas pada neraca keuangannya agar bisa lebih baik dalam mengelola dana yang berasal dari uang kas untuk menghasilkan keuntungan yang optimal.

\section{Rasio Solvabilitas \\ Tabel 4 : Perhitungan Rasio Hutang Terhadap Aset}

$$
\begin{aligned}
& \text { Terhadap Aset } \\
& \begin{array}{rl|}
2016= & \frac{226.862 .000}{3.531 .989 .022} \times 100 \%=6,42 \% \\
2017 & =\frac{5.455 .362 .000}{10.705 .698 .597} \times 100 \%=50,96 \% \\
2018 & =\frac{5.623 .850 .000}{32.379 .452 .525} \times 100 \%=17,37 \%
\end{array}
\end{aligned}
$$

Sumber : Data diolah

Standar industri untuk rasio hutang terhadap aset adalah maksimal 35\%. Dalam hal tersebut menunjukkan kecukupan modal terhadap aset perusahaan maka tingkat keamanan dananya pun semakin baik. Langkah yang seharusnya dilakukan adalah sebaiknya perusahaan dapat meningkatkan nilai aset perusahaan dengan dana yang berasal dari modal sendiri tanpa dibelanjai oleh hutang dari phiak ketiga. 
Tabel 5 : Perhitungan Rasio Hutang Terhadap Ekuitas

$\begin{aligned} 2016= & \frac{226.862 .000}{3.305 .127 .022} \times 100 \%=6,86 \% \\ 2017= & \frac{5.455 .362 .000}{5.250 .336 .597} \times 100 \%=103,90 \% \\ 2018= & \frac{5.623 .850 .000}{26.829 .206 .326} \times 100 \%=20,96 \%\end{aligned}$

Sumber : Data diolah

Standar industri untuk rasio hutang terhadap ekuitas yaitu maksimal $90 \%$. Dimana dengan ini perusahaan menunjukkan kecukupan modal dalam menjalankan usahanya tidak tergantung dengan hutang maka tingkat keamanan dananya juga semakin baik. Langkah yang seharusnya dilakukan adalah menerapkan kebijakan mengenai hutang jangka pendek maupun jangka panjang yang tidak lebih besar dari modal sendiri yang tertanam pada perusahaan tersebut untuk memperbaiki keadaan perusahaan kedepannya.

\section{Rasio Aktivitas}

Tabel 6 : Perhitungan Rasio Perputaran Persediaan

$2016=\frac{8.396 .800 .000}{865.689 .600}=10 \times$
$2017=\frac{8.141 .724 .144}{5.906 .890 .460}=1 \times$
$2018=\frac{38.242 .467 .080}{14.169 .876 .800}=3 \times$

Sumber : Data diolah

Standar industri untuk perputaran persediaan adalah minimal 20 kali pada per tahunnya. Dalam hal tersebut perusahaan belum mampu untuk mengembalikan dana nya yang tertanam pada persediaan yang berputar dalam suatu periode. Langkah yang seharusnya dilakukan sebaiknya perusahaan pada bagian manajemen persediaan dapat mengatur persediaan barang yang dimiliki dengan baik dengan cara memastikan persediaan yang cukup, efisiensi terhadap biaya persediaan, dan memastikan persediaan diperlakukan dengan optimal.
Tabel 7 : Perhitungan Rasio Perputaran Aset Tetap

$2016=\frac{10.240 .000 .000}{63.958 .329}=160 \times$
$2017=\frac{11.008 .000 .000}{53.333 .325}=206 \times$
$2018=\frac{57.136 .600 .000}{18.076 .537 .425}=3 \times$

Sumber : Data diolah

Standar industri rasio perputaran aset yaitu minimal 5 Kali. Dengan ini menunjukkan perusahaan tidak menggunakan asetnya secara efektif dan efisien. Langkah yang seharusnya dilakukan sebaiknya perusahaan dapat mengelola aset tetap dengan tepat, dengan ini maka akan diperoleh keuntungan yang begitu besar karena dapat mengoptimalkan kinerja dan manfaat dari aset tetap tersebut.

Tabel 8 : Perhitungan Rasio Perputaran Aset

$\begin{aligned} 2016 & =\frac{10.240 .000 .000}{3.531 .989 .022}=3 \times \\ 2017 & =\frac{11.008 .000 .000}{10.705 .698 .597}=1 \times \\ 2018 & =\frac{57.136 .600 .000}{32.379 .452 .525}=2 \times\end{aligned}$

Sumber : Data diolah

Standar industri rasio perputaran aset yaitu minimal 2 Kali. Dalam hal tersebut perusahaan telah efisien dalam menggunakan asetnya untuk menghasilkan penjualan. Langkah yang seharusnya dilakukan sebaiknya perusahaan dapat meningkatkan lagi dalam memanfaatkan aset yang dimiliki secara maksimal untuk menghasilkan penjualan yang tinggi. Dengan diperolehnya penjualan yang tinggi maka juga akan berdampak pada tercukupinya kas perusahaan serta nilai perolehan keuntungan yang semakin tinggi. 


\section{Rasio Profitabilitas}

Tabel 9: Perhitungan Rasio Margin Laba Kotor

$\begin{aligned} 2016= & \frac{1.843 .200 .000}{10.240 .000 .000} \times 100 \%=18 \% \\ 2017= & \frac{2.866 .275 .865}{11.008 .000 .000} \times 100 \%=26,04 \% \\ 2018= & \frac{18.894 .132 .920}{57.136 .600 .000} \times 100 \%=33,07 \%\end{aligned}$

Sumber : Data diolah

Standar industri rasio margin laba kotor yaitu minimal 30\%. Dengan ini menunjukkan perusahaan tersebut mampu untuk menjalankan produksinya secara efisien karena harga pokok penjualannya relatif lebih rendah jika dibandingkan dengan penjualan. Langkah yang seharusnya dilakukan sebaiknya perusahaan dapat meningkatkan lagi Dengan cara meminimalkan biaya produksi seperti membeli bahan baku dari produsen yang lebih murah namun dengan kualitas yang lebih baik.

Tabel 10 : Perhitungan Rasio Margin Laba Bersih

\begin{tabular}{|c|c|c|c|}
\hline \multirow[t]{2}{*}{2016} & $=1.505 .150 .546$ & \multirow{2}{*}{$100 \%=$} & \multirow{2}{*}{$14,70 \%$} \\
\hline & 10.240 .000 .000 & & \\
\hline \multirow[t]{2}{*}{2017} & $=\quad 2.743 .430 .802$ & \multirow{2}{*}{$100 \%=$} & \multirow{2}{*}{$24,92 \%$} \\
\hline & 11.008 .000 .000 & & \\
\hline \multirow[t]{2}{*}{2018} & $=17.578 .869 .729$ & \multirow{2}{*}{$100 \%=$} & \multirow{2}{*}{$30,77 \%$} \\
\hline & 57.136 .600 .000 & & \\
\hline
\end{tabular}

Sumber : Data diolah

Standar industri untuk rasio margin laba bersih yaitu minimal 20\%. Dengan ini menunjukkan operasional yang efisien sehingga perusahaan mampu memaksimalkan laba bersih yang didapatkan. Langkah yang seharusnya dilakukan meningkatkan lagi kedepannya dalam menghasilkan laba bersih yang lebih besar dengan cara menekankan biaya-biaya yang tidak perlu.

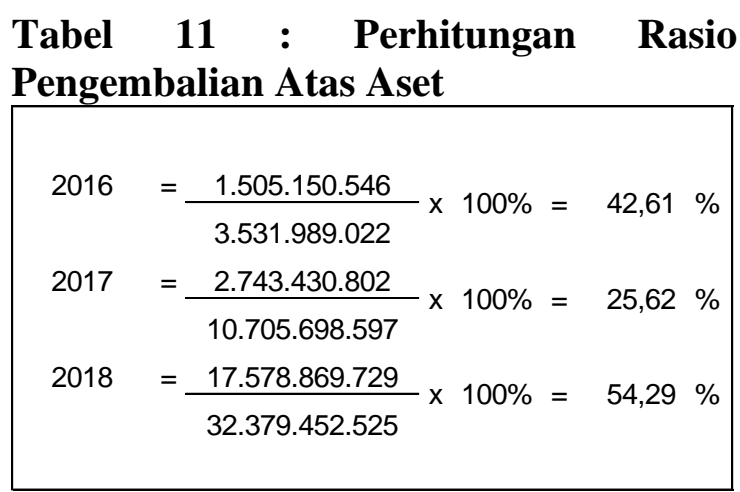

Sumber : Data diolah

Standar industri rasio pengembalian atas aset yaitu minimal 30\%. Dengan ini menunjukkan perusahaan mempunyai kinerja yang bagus dalam menghasilkan laba bersih untuk pengembalian total aset. Langkah yang seharusnya dilakukan sebaiknya perusahaan dapat meningkatkan lagi kedepannya dengan cara mengambil keputusan yang tepat untuk menggunakan utang dalam jumlah yang besar, dan juga beban bunga yang tinggi menyebabkan laba bersih menjadi relatif lebih rendah.

Tabel 12 : Perhitungan Rasio Pengembalian Atas Modal

$\begin{aligned} & 2016= \frac{1.505 .150 .546}{3.305 .127 .022} \times 100 \%=45,54 \% \\ & 2017= \frac{2.743 .430 .802}{5.250 .336 .597} \times 100 \%=52,25 \% \\ & 2018=\frac{17.578 .869 .729}{26.829 .206 .326} \times 100 \%=65,52 \%\end{aligned}$

Sumber : Data diolah

Standar industri rasio pengembalian atas modal yaitu minimal 40\%. Dengan ini menunjukkan perusahaan mampu mengelola modal sendiri secara efektif sehingga menghasilkan keuntungan dari investasi yang telah dilakukan pemilik modal sendiri atau pemegang saham perusahaan. Langkah yang seharusnya dilakukan sebaiknya perusahaan dapat meningkatkan lagi dengan cara menghitung berapa banyak uang yang dapat dihasilkan oleh perusahaan berdasarkan uang yang diinvestasikan pemegang saham. 


\section{Rasio Pertumbuhan}

Tabel 13 : Perhitungan Rasio Kenaikan Penjualan

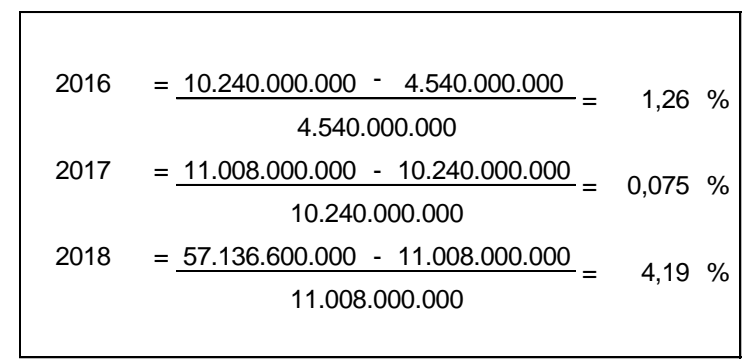

Sumber : Data diolah

Standar industri rasio kenaikan penjualan yaitu minimal $20 \%$. Dengan ini perusahaan menghasilkan penjualan ke arah yang lebih baik yaitu terjadi kenaikan jumlah penjualan dari tahun ketahun berikutnya. Langkah yang seharusnya dilakukan perusahaan dapat meningkatkan lagi laju pertumbuhan dengan peningkatan yang konsisten dalam aktivitas utama operasinya. Dengan cara melakukan promosi yang menarik, dan juga memastikan bahwa promosi yang ditargetkan sesuai sehingga upaya yang dilakukan akan membuahkan hasil yang serupa.

Tabel 14 : Perhitungan Rasio Kenaikan Laba Bersih

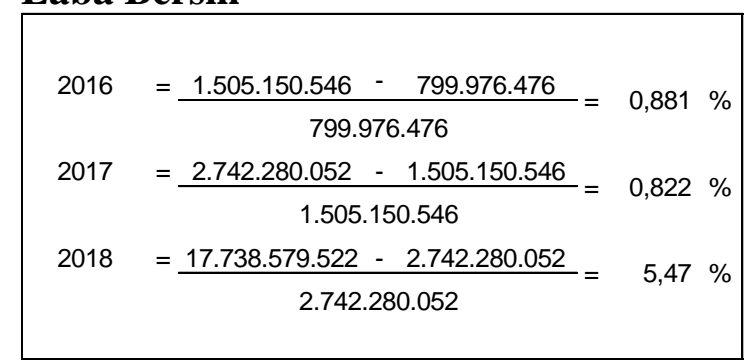

Sumber : Data diolah

Standar industri rasio kenaikan laba yaitu minimal 20\%. Dengan ini perusahaan menghasilkan ke arah yang lebih baik yaitu terjadi laba bersih yang terus meningkat dari tahun ketahun berikutnya. Langkah yang seharusnya dilakukan sebaiknya perusahaan dapat meningkatkan lagi laju pertumbuhan dengan peningkatan yang konsisten dalam mempertahankan keuntungan. Dengan cara melakukan mengevaluasi tingkat penjualan melalui aktivitas promosi dan pemasaran, serta tingkat laba marginal.

\section{KESIMPULAN}

Berdasarkan analisis laporan keuangan PT. Dzaky Indah Perkasa Cabang Sungai Tabuk untuk mengukur kinerja dengan menggunakan analisis rasio keuangan, maka dapat ditarik kesimpulan sebagai berikut :

1. Analisis laporan keuangan yang selama ini sebagai alat untuk mengukur kinerja keuangan pada PT. Dzaky Indah Perkasa Cabang Sungai Tabuk belum melakukan analisis terhadap laporan keuangan sesuai dengan standar industri dikarenakan perusahaan dalam mengukur tingkat keberhasilan suatu usaha hanya menggunakan cara sederhana yaitu dengan mengacu kepada laporan keuangan yang disajikan pada tiap periode dimana dapat diukur dari keuntungan atau kerugian yang dihasilkan dari usaha yang dijalankan.

2. Analisis laporan keuangan yang seharusnya sebagai alat untuk mengukur kinerja keuangan pada PT. Dzaky Indah Perkasa Cabang Sungai Tabuk, dari hasil perhitungan menggunakan rasio keuangan tingkat kinerja keuangan yang baik diperoleh dari rasio likuiditas, solvabilitas, dan profitabilitas, hal ini dikarenakan perusahaan memiliki aset lancar yang cukup besar sehingga dapat menjalankan usaha tanpa dibiayai oleh pihak ketiga dan dapat memperoleh keuntungan yang maksimal. Sedangkan tingkat kinerja keuangan yang kurang baik diperoleh dari rasio aktivitas dan pertumbuhan, hal ini dikarenakan perusahaan belum mampu dalam mengembalikan dan menghasilkan dana/aset yang tertanam dalam suatu periode sehingga menyebabkan tingkat kenaikan dari penjualan serta laba yang dihasilkan relatif kecil. Berdasarkan pengukuran kinerja tersebut agar kondisi perusahaan menjadi lebih baik kedepan yang seharusnya dilakukan adalah 
perusahaan mampu mengelola dana yang tertanam dengan baik sehingga dapat berputar dalam suatu periode untuk mendapatkan keuntungan yang optimal dengan menerapkan strategi pemasaran $4 \mathrm{P}$ yang terdiri dari product, price, place, promotion.

\section{SARAN}

Adapun saran dalam penelitian ini adalah PT. Dzaky Indah Perkasa Cabang Sungai Tabuk hendaknya perlu mengetahui kinerja perusahaan dengan menggunakan analisis rasio keuangan. Karena pendapatan yang terus meningkat dan perolehan keuntungannya yang juga meningkat belum tentu dalam kinerja keuangan pada perusahaan tersebut secara keseluruhan dalam kondisi baik sesuai dengan standar. Dengan ini maka PT. Dzaky Indah Perkasa Cabang Sungai Tabuk diharapkan dapat memperbaiki tingkat kinerja keuangannya yang selama ini kurang baik untuk kedepannya sesuai dengan standar industri keuangan yang telah ditetapkan dan juga dapat menjadi dasar serta bahan pertimbangan dalam pengambilan keputusan bagi manajemen.

\section{DAFTAR PUSTAKA}

Bitar, 2019. Pengertian Akuntansi Menurut Para Ahli.

https://www.gurupendidikan.co.id/p engertian-akuntansil. (Diakses pada tanggal 14 September 2019).

Fahmi, Irham. 2014. Analisis Kinerja Keuangan.

Bandung: Alfabeta. 2015. Analisis Laporan Keuangan. Cetakan Ke-5.

Bandung: Alfabeta.

Harahap, Sofyan Safri. 2016. Analisis Kritis Atas Laporan Keuangan. Jakarta: Rajawali Pers.

Harmono, 2014, Manajemen Keuangan: Berbasis Balance Scorecard,

PT. Bumi Aksara, Jakarta.

Harrison, Walter. T. 2015. Akuntansi Keuangan: International Financial Reporting Standars. Penerjemah Gina Gania. Jakarta : Erlangga
Ikatan Akuntansi Indonesia. 2015. PSAK No.1 Laporan Keuangan- Revisi 2015.

Penerbit Dewan Standar Akuntansi Keuangan : PT. Raja Grafindo.

Standar Akuntansi Keuangan.

Jakarta : Penerbit Salemba Empat.

Istiqomah, Nurul. 2017. "Analisis Rasio

Keuangan Untuk Menilai Kinerja

Keuangan Perusahaan Sub Sektor

Semen Yang Terdaftar Di Bursa

Efek Indonesia". eJournal

Administrasi Bisnis, UnMul. 2017, 5 (4): 917-931 ISSN 2355-5408.

Jumingan. 2014. Analisis Laporan

Keuangan.

Jakarta : Media Grafika.

Kasmir. 2014. Analisis Laporan Keuangan, Edisi Pertama, Cetakan Ketujuh. Jakarta: PT. Rajagrafindo Persada. . 2016. Analisis Laporan Keuangan. Jakarta: Rajawali Pers.

Najmudin,2011, Manajemen Keuangan dan Akuntansi Syar'iyyah Modern,

CV. Andi Offset, Yogyakarta.

Rudianto. 2013. Akuntansi Manajemen

Informasi Untuk Pengambilan

Keputusan Strategis. Jakarta :

Erlangga.

Sugiyono. 2017. Metode Penelitian

Kuantitatif, Kualitatif, dan $R \& D$.

Bandung: Alfabeta.

Sujarweni, V. Winatra. 2016. Pengantar Akuntansi.

Yogyakarta: Pustaka Baru Press. 